\title{
Economic feasibility analysis and optimization of hybrid renewable energy systems for rural electrification in Peru
}

\author{
Fabio Rinaldi ${ }^{1} \cdot$ Farzad Moghaddampoor $^{1} \cdot$ Behzad Najafi $^{1}$ (D) $\cdot$ Renzo Marchesi $^{1}$
}

Received: 4 January 2020 / Accepted: 21 July 2020 / Published online: 31 July 2020

(c) The Author(s) 2020

\begin{abstract}
The majority of rural communities in developing countries (such as Peru) are not connected to the electrical grid. Hybrid energy production from available renewable resources (e.g., wind and solar) and diesel engines is considered as an economically viable and environmentally friendly alternative for electrification in these areas. Motivated by the lack of a comprehensive investigation dedicated to the techno-economic analysis of hybrid systems (PV-wind-diesel) for off-grid electrification in Peru, the present work is focused on determining the optimal configuration of these systems for remote Peruvian villages. Three small communities without access to the grid (Campo serio, El potrero, and Silicucho), which are located in different climatic zones of Peru, have been accordingly selected as case studies. Seven different configurations including single component systems (solar, wind, and diesel) and hybrid ones are considered. While taking into account the meteorological data and load characteristics of the communities along with the diesel fuel's price and the cost of components, HOMER software is utilized to determine the optimal sizing of the system [resulting in the lowest net present cost (NPC)] considering different scenarios. The obtained configurations are then compared considering other state-of-the-art economic indices [initial capital cost, total annual operating cost, and the cost of energy (COE)], the generation fractions, and the resulting $\mathrm{CO}_{2}$ emissions. The obtained results have revealed that, for all of the investigated communities, the hybrid solar-wind-diesel system is the most economically viable scenario. Considering the latter scenario, the obtained optimal configuration leads to an NPC of USD 227,335 (COE: $0.478 \mathrm{USD} / \mathrm{kWh}$ ) for Campo serio, USD 183,851 (COE: 0.460 USD/kWh) for El potrero, and USD 146,583 (COE: $0.504 \mathrm{USD} / \mathrm{kWh}$ ) for Silicucho. Furthermore, employing the optimal configurations a renewable fraction (with respect to the total generation) of $94 \%$ is obtained for Campo serio and Silicucho, while the achieved renewable fraction for El potrero is $97 \%$. Moreover, for the case of Campo serio, the resulting $\mathrm{CO}_{2}$ emission of the obtained optimal system is determined to be $6.1 \%$ of that of a diesel-only unit, while the latter ratio is determined to be $2.7 \%$ for El potrero and $9.9 \%$ for that of Silicucho. The optimal configurations that are obtained and presented in the present paper can be utilized as guideline for designing electrification systems (with a minimized cost) for the considered communities and other villages with similar characteristics (population and climatic conditions).
\end{abstract}

Behzad Najafi

behzad.najafi@polimi.it

1 Dipartimento di Energia, Politecnico di Milano, Via

Lambruschini 4, 20156 Milan, Italy 


\section{Graphic abstract}

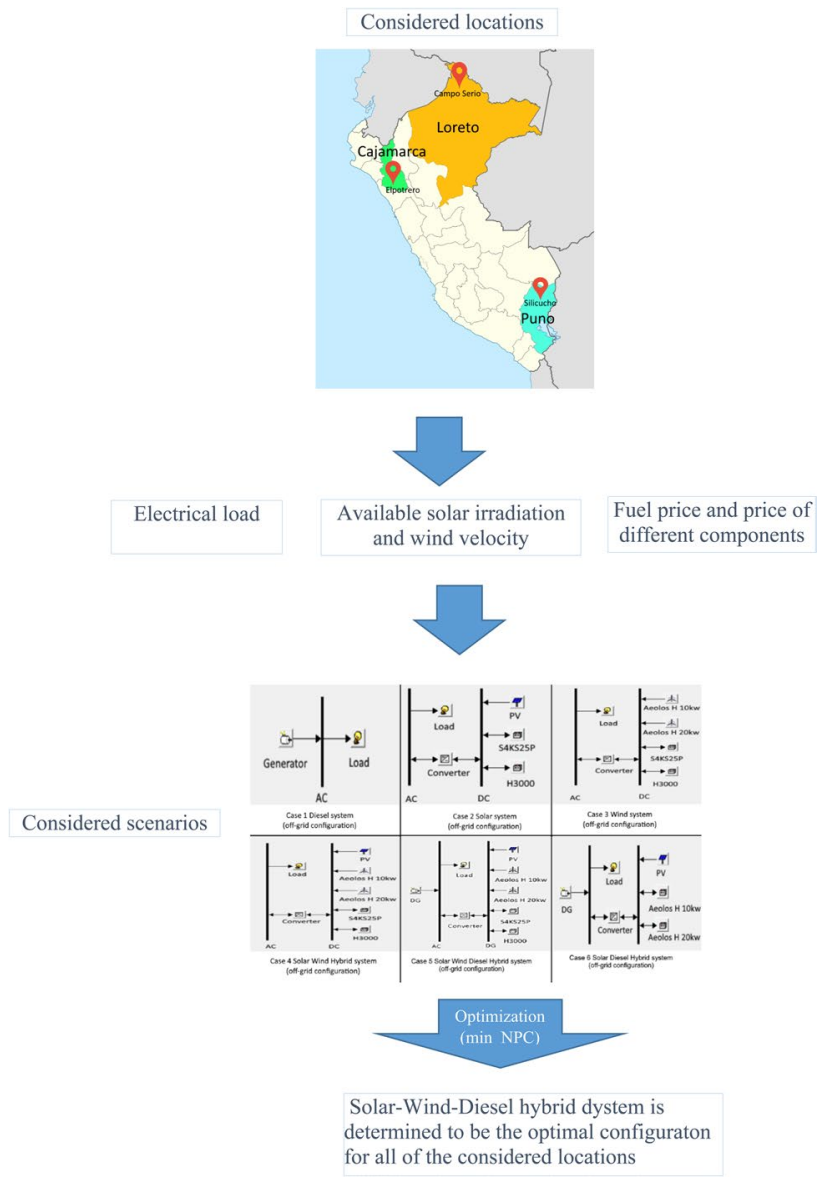

Keywords Hybrid energy system · Rural electrification · Photovoltaic $\cdot$ Wind $\cdot$ Economic feasibility analysis $\cdot$ HOMER

\author{
List of symbols \\ C Cost (USD) \\ COE Levelized cost of energy (USD/kWh) \\ CRF Capital recovery factor $(-)$ \\ E Energy $(\mathrm{kWh} / \mathrm{year})$ \\ $f \quad$ Energy fraction (-) \\ $i \quad$ Annual real interest rate (-) \\ $N \quad$ System lifetime (year) \\ NPC Net present cost (USD) \\ $R \quad$ Remaining cost (USD) \\ RF Renewable fraction (-) \\ TAC Total annualized cost (USD) \\ TOC Total operating cost (USD) \\ USD American dollar
}

\section{Subscripts}

ann Annualized

DG Diesel generator

f Fuel

$\mathrm{OM}$ Operating and maintenance

$\begin{array}{ll}\text { R } & \text { Replacement } \\ \text { S } & \text { Salvage } \\ \text { tot } & \text { Total } \\ \text { W } & \text { Wind }\end{array}$

\section{Introduction}

Power access is at the forefront of governments' preoccupations, particularly in nations in which electricity is essential for certain basic activities such as lighting, refrigeration and running of household appliances (Kanase-Patil et al. 2010). The vast majority of rustic communities in developing countries like Peru are not entirely connected to electrical grid due to geographical obstacles and small population, which make the required investments for grid extension unjustifiable. Energy production from available and sustainable sources such as wind and sun has been considered as a viable and environmentally friendly alternative (Mamaghani et al. 
2016b). Due to the ever-increasing price of petroleum derivatives on a global scale and concerns regarding the emission of greenhouse gases (GHG) (Najafi et al. 2015), remarkable attention has been directed toward green renewable technologies for catering growing energy demand (Mamaghani et al. 2017).

Renewable energy sources (RES) are abundant in most parts of the world, and, unlike fossil fuels, can be harnessed without any cost for the resource. In this regard, many governments have already started to finance renewable technologies by means of direct grants, loans and tax incentives (Liu et al. 2012). Electricity generation in Peru through hydro, wind, solar, geothermal, biomass, tidal power or other RES is subjected to an annual maximum $20 \%$ depreciation regime for income tax purposes (Irena 2014).

Despite the aforementioned upsides of RES, there are a number of technical difficulties which must be resolved to make renewable energy systems reliable and self-sufficient. The most important issue with the electricity generation by RES is the lack of stability which stems from their intermittent nature. Such nature is due to the variations in the atmospheric conditions which can result in substantial fluctuations in power generation seasonally or even daily (Bekele and Boneya 2012). To provide a stable supply of electrical power, the application of power storage systems such as batteries (Fragaki and Markvart 2008) or combining RES with non-renewable technologies such as diesel, natural gas or biomass driven generators (Montuori et al. 2014) have been proposed in the previous studies. Hybrid energy systems, which usually comprise of at least two power sources, have been utilized to reach higher electrical efficiency and more uniform power supply. Another shortcoming of RES is the significantly higher capital cost of such systems, compared to the conventional diesel generators. Nevertheless, with respect to stand-alone diesel generators, hybrid systems require less fossil fuel (Kalantar and Mousavi 2010) (i.e., reducing operational cost), reduce carbon footprints (Bentouba and Bourouis 2016), while enhancing quality of service (Valente and De almeida 1998). For some configurations of RES projects including the wind turbine-based units, the cost of energy (COE) and net present cost (NPC) can be notably decreased by expanding the capacity of the installed power system and addressing a higher electrical load (Diab et al. 2016). Since several factors [such as different possible combinations of RES and non-RES sources, the demand profile, seasonal availability of RES, capital cost of components, and the fuel cost (Aminyavari et al. 2016)] must be considered while attempting to determine optimal configuration of hybrid energy systems, optimization tools should be utilized in order to obtain a comprehensive evaluation of different scenarios (Gu et al. 2017). Genetic algorithm (Najafi et al. 2011), cuckoo search algorithm (Ray et al. 2018), modified electric system analysis (Zahboune et al. 2016), and game theory (Khare et al. 2016) are some of the frequently utilized techniques that are employed for optimizing the sizing of components (Rajkumar et al. 2011) aiming at minimizing the cost (Yousefi et al. 2017) of these systems. Arceo et al. (2018) demonstrated that, by utilizing the optimal configuration of a hybrid electrification system in remote areas of Western Australia, the overall environmental impact is reduced by $16 \%$, although it leads to increasing the total life cycle costs by $4 \%$. Roy and Kulkarni (2016) determined the optimal configuration of a PV-diesel generator hybrid system for rural areas in India, using which $70 \%$ of the energy demand is met by the diesel generator and 30\% is addressed by the PV panels. Flores et al. (2016) optimized (through minimizing the COE) the configurations of hybrid wind, $\mathrm{PV}$, and biomass-based generation for rural electrification in Honduras. Hrayshat (2009) showed that utilizing the optimal configuration of hybrid wind-diesel generation units in remote Jordanian settlements leads to an annual reduction of $21.3 \%$ in the diesel consumption.

Several works have utilized hybrid optimization model for electric renewables (HOMER) software to perform techno-economic feasibility study, sensitivity analysis, and optimization (Singh and Baredar 2016) on hybrid microgrids (Dekker et al. 2012). The optimal configuration of PV and battery system, which was obtained using HOMER in a study conducted by Alsharif (2017), was demonstrated to be an energy efficient and cost-effective alternative for supplying heterogeneous cellular networks. In another study conducted using HOMER, Brandoni and Bošnjakovic (2017) demonstrated that using the obtained optimal configuration of a hybrid system (constituting of PVs, wind turbines and internal combustion engines) $33-55 \%$ of the energy demand of a wastewater facility located in Sub-Saharan Africa can be addressed, while the COE is lower than the local cost of electricity. Marneni et al. (2015) instead used HOMER to find the optimal sizing of solar photovoltaic generation to enhance the voltage profile of a rural feeder (3.06 MW peak load) in Mysuru, India.

It is generally accepted that answering the electrical demand by hybrid systems (i.e., more than one RES or non-RES) is more logical than only depending on RES. This stems from the fact that naturally reliance on a single RES necessitates over-sizing the system to be able to cater the demand considering the variations in solar irradiation/ wind speed throughout the day or seasonally. Many studies have been dedicated to performance evaluation and feasibility analysis of hybrid systems such as PV-wind units (Arribas et al. 2010), wind-diesel-battery, and wind-fuel cell systems (Khan and Iqbal 2005). Shaahid and Elhadidy (2007) performed a techno-economic feasibility analysis on a hybrid PV-diesel-battery system. In a similar study conducted for the case study of Ireland, it was found that, owing to the climatic characteristics of the area, wind is 
the dominant component of the majority of optimal hybrid power systems (Goodbody 2013). In a study comparing PV-diesel and PV-battery systems, it was concluded that the former is by far more cost-effective for loads higher than $13 \mathrm{kWh} /$ day while the latter is more economical for 3-13 $\mathrm{kWh}$ /day range (Lilienthal 2015). PV-wind-diesel-battery hybrid system was observed to be the most practical option (Bekele and Palm 2010) to supply a community model living in an Ethiopian remote area.

Regarding the environmental impacts of hybrid systems, Hafez and Bhattacharya (2012) assessed the emissions of a microgrid arrangement including diesel, wind, PV, battery, and hydro and the $\mathrm{CO}_{2}$ emission were estimated to be 1078.4 t/year. A study conducted by Ajlan et al. (2017) revealed that the PV-wind and PV-wind-diesel can reduce the $\mathrm{CO}_{2}$ emission by $100 \%$ and $70 \%$ and the $\mathrm{COE}$ by $30 \%$ and $45 \%$ with respect to the diesel generators. In another study (Shezan et al. 2015), it was shown that the optimal configuration of wind-DG-battery systems results in a renewable fraction (RF) of 0.0914. In another conducted by Hossain et al. (2017), which was focused on electrification for tourist resorts in Malaysia, it was concluded that the obtained optimal configuration of wind-diesel-battery hybrid system results in a lower $\mathrm{COE}(0.279$ vs $0.343 \mathrm{USD} / \mathrm{kWh})$ and $\mathrm{CO}_{2}$ emission $(2,571,131 \mathrm{~kg} /$ year vs $5,432,244 \mathrm{~kg} /$ year $)$ compared to the diesel-only system; which make it a promising alternative for reducing the carbon emission intensity (Hossain et al. 2015) in these areas. Rajbongshi et al. (2017) showed that the COE for a grid-connected hybrid system is lower than an off-grid one for similar load profiles due to the fact that grid-tied systems allow export of excess electricity into the grid rather than storing it with battery. Regarding the impact of projected variations in influential parameters, Dorji et al. (2012) stated that 20\% drop in the price of PV led to $4.9-8 \%$ decrease in NPC.

Despite the promising potentials of RES for power production in Peru and existence of abundant resources, feasibility studies to explore green and cost-effective technologies such as PV or wind are scarce. To the best of our knowledge, there is no thorough study on techno-economic analysis of hybrid systems (PV-Wind-Diesel) in Peru. The present work aims at finding the optimal combination of available RES to satisfy the energy demand of three offgrid villages in Peru. These territories have been selected according to geographical and population consultation centre of Peru (INEI 2012). INEI (2012) provides statistical data such as population, access to power network, and distance from large urban areas. Meteorological data of solar irradiation and wind speed were borrowed from NASA atmospheric science data center using the location of each community (NASA 2017). Solar irradiation, wind speed, and electricity demand of each community are provided as inputs to HOMER software to conduct the techno-economic analysis. Seven different possible scenarios including single component systems (diesel, solar, or wind) and hybrid ones (Solar-Wind, Solar-Diesel, Wind-Diesel, or Solar-Wind-Diesel) are considered. Each of these scenarios is modeled in HOMER software and, considering the NPC as the economic main index, their corresponding optimal sizing is determined. The obtained configuration is next evaluated based on various economic and environmental criteria including the initial capital cost, operating cost, $\mathrm{COE}, \mathrm{RF}$ and pollutants emission rates. Since HOMER is utilized in this study, it incorporates all of the limitations of the corresponding models; however, it has extensively been recognized as a promising tool in the literature to achieve the defined aims of the present study.

\section{Description of the considered areas}

\section{Location and population}

Peru has one of the lowest rural electrification rates in Latin America (INEI 2012). Considerable efforts have been made to extend Peru's national grid as part of the country's plan to augment rural electrification from 71 to $88.2 \%$ between 2013 and 2017 (SE4All 2014). For this study, three regions with drastically low power coverage, Cajamarca, Puno and Loreto, have been selected (SE4All 2014). Electrification via grid network to these areas is inconceivable because of impassable routes through the rough mountains, forests and dispersion of the settlements. The vast majority of population in these areas suffer from poverty and cannot afford expenses of electrical installations and maintenance (Rehman et al. 2007). Based on the master plan of rural electrification with RES of Peruvian ministry of mine and energy (MINEM Peru 2008), three small residential communities were chosen from previously mentioned regions.

The regions with lack of access to electricity grid and the chosen communities within these regions are demonstrated in Fig. 1. Loreto is Peru's northernmost region with very small population due to its remote location in the Amazon Rainforest. Cajamarca is situated in the northern highlands of Peru with a tropical climate which is characterized by mild and sunny days. Puno is located in south-eastern of Peru at high elevation which results in harsh climate conditions compared to the other selected communities. Table 1 summarizes the geographic and demographic information and climatic characteristics of these communities.

\section{Load estimation}

Current population of each community has been extracted from the last national surveys provided by INEI (2012). Energy demands of each town were estimated by considering 


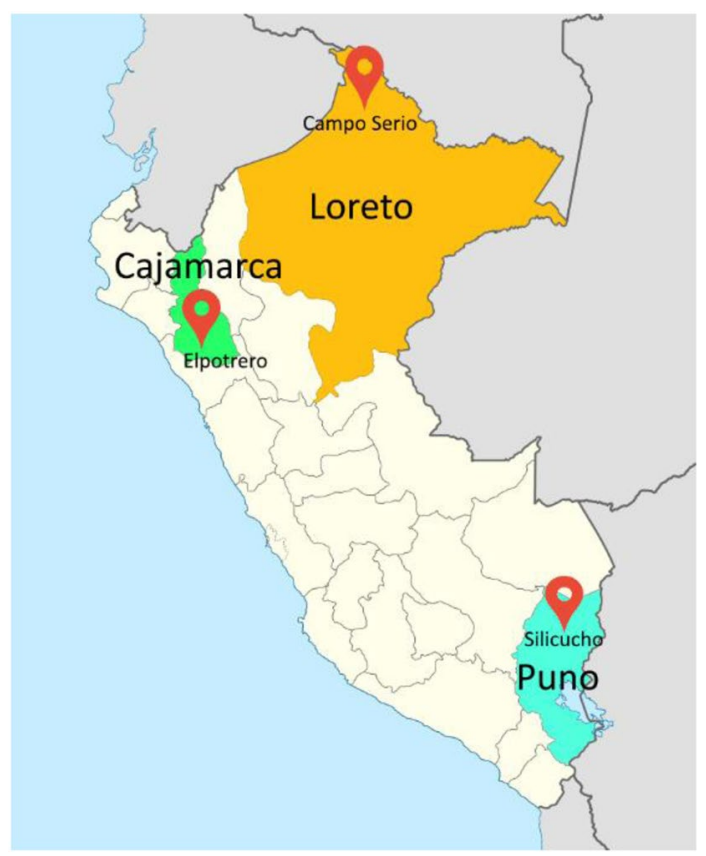

Fig. 1 Location of the considered areas in Peru

Table 1 Characteristics of the selected areas

\begin{tabular}{lllll}
\hline Area & & Geography & Climate & \\
\cline { 1 - 1 } \cline { 5 - 5 } Community & Region & Altitude $(\mathrm{m})$ & $\begin{array}{l}\text { Pre- } \\
\text { cipitation } \\
(\mathrm{mm})\end{array}$ & $\begin{array}{l}\text { Average annual } \\
\text { temperature } \\
\left({ }^{\circ} \mathrm{C}\right)\end{array}$ \\
\hline Campo Serio & Loreto & 161.1 & 2880 & 25 \\
El potrero & Cajamarca & 2099.4 & 725.5 & 15.1 \\
Silicucho & Puno & 4356.6 & 689.7 & 9.8 \\
\hline
\end{tabular}

Fig. 2 Daily electrical load profile during weekdays for Campo serio the fundamental needs of individuals such as lighting and communication. The maximum connected load for each house is assessed to be $81 \mathrm{~W}$ including lighting (36 W fluorescent lamps), communication ( $15 \mathrm{~W}$ radio receiver) and a reserve $(30 \mathrm{~W})$. Number of houses is determined considering the population of each community. It should be highlighted that since people in these areas are mostly involved in farming and livestock breeding, they spend most of their day outside of the house, and, thereby, most of the energy consumption takes place in the early night. Two essential services, a health center and a school with loads of $1.4 \mathrm{KW}$ and $1.3 \mathrm{KW}$, were taken into account during analysis. For the school eight $36 \mathrm{~W}$ fluorescent lamps are considered as well as computers, printers and a TV. It was assumed that students attend the classes from 8:00 a.m. to 13:00 p.m. For the case of health center, appliances such as refrigerator for storing medicines, radios and lighting were considered. Public lighting of $400 \mathrm{~W}$ for each group of 5 houses was considered in the calculation of load profile for these areas. These approximations are made based on the guideline presented by Bekele and Boneya (2012), which introduced an approach to obtain the load distribution during the day. Figure 2 displays the hourly distribution of the overall load during workdays and weekends in Campo Serio. For the case of brevity only the load profile of this community is presented. It can be observed that the electricity consumption declines in January, February, and March in Peru schools are closed from January to March as a result of the termination of the academic year.

The determined overall load profile of each community is then provided to HOMER. Next, in order to add randomness to the load data to make it more realistic, timestep-to-time-step and day-to-day variability values of $20 \%$ and $15 \%$ are applied to the provided raw data. The peak load in the generated profile for Campo Serio, El Potrero, and Silicucho is determined to be $18.9 \mathrm{~kW}, 15.1 \mathrm{~kW}$ and

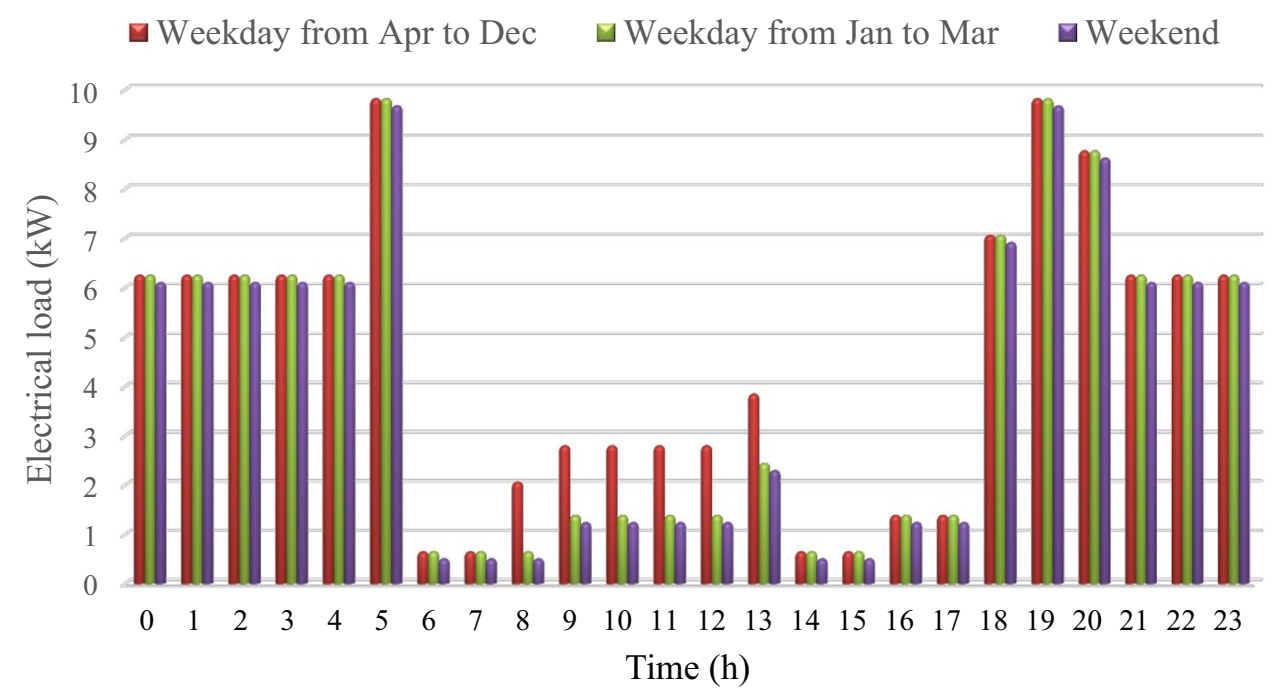


Fig. 3 Average electrical load for each location

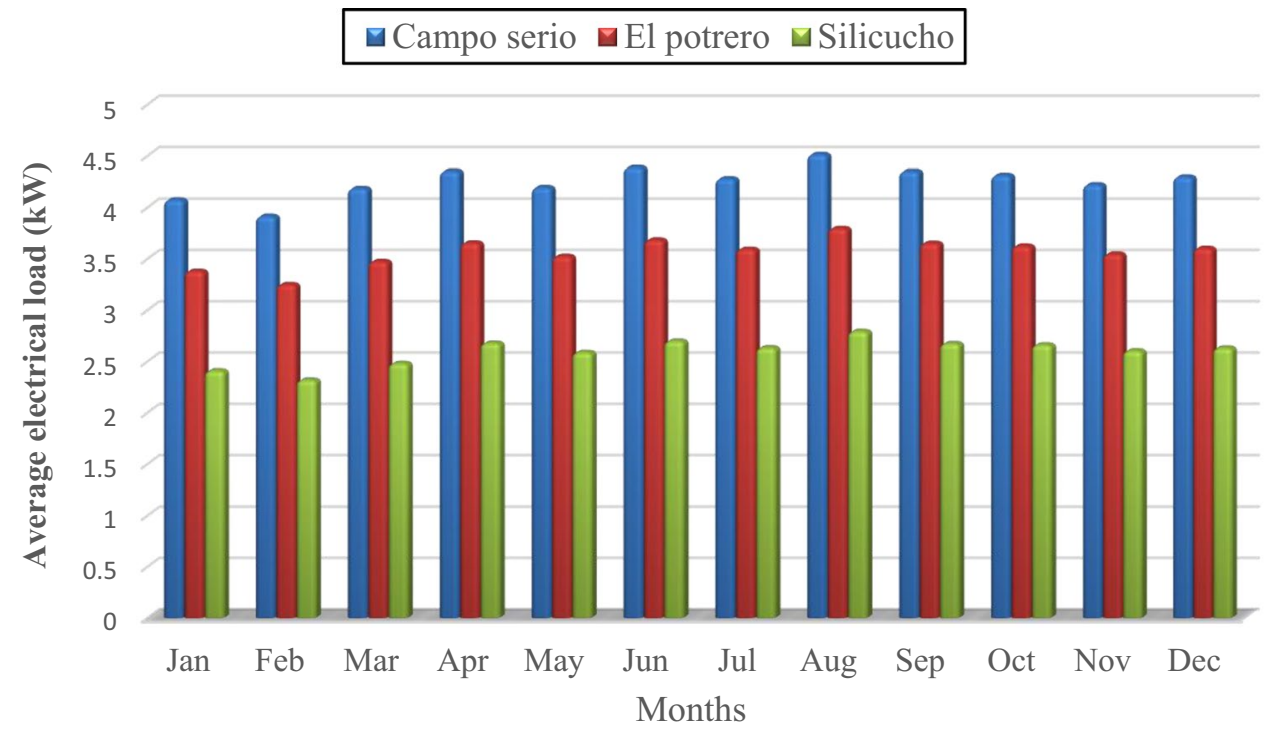

$9.8 \mathrm{~kW}$. Figure 3 depicts the average load, based on the generated load profiles, for each months of the year for the considered communities. The determined average yearly load for Campo serio, El potrero, and Silicucho is $4.3 \mathrm{~kW}$, $3.6 \mathrm{~kW}$, and $2.6 \mathrm{~kW}$.

\section{Availability of energy resources}

\section{Solar irradiation}

Utilizing the climatic information from NASA surface meteorology and solar energy (NASA 2017), the average monthly solar irradiations are determined for each location (Fig. 4a). Among selected communities, El potrero has the highest average yearly irradiation $\left(3.145 \mathrm{kWh} / \mathrm{m}^{2}\right)$ and Silicucho has the lowest one $\left(2.326 \mathrm{kWh} / \mathrm{m}^{2}\right)$. As can be noticed in Fig. 4a, during winter (months of May-July), solar irradiation reaches its lowest values, leading to small power production from the PV source.

\section{Wind speed}

Average monthly data for wind speed have been extracted from NASA surface meteorology and solar energy (NASA 2017). As displayed in Fig. 4b, Silicucho is the windiest region among all of selected communities with average wind speed of $7.16 \mathrm{~m} / \mathrm{s}$. Due to the fact that HOMER calculates the generated power based on the wind speed at the hub height, the altitude of each area should be given as input to the software. HOMER uses logarithmic law to assess the speed of wind at the hub height, as described in Eq. (1).
$\frac{V\left(z_{\text {hub }}\right)}{V\left(z_{\text {anem }}\right)}=\frac{\ln \left(\frac{z_{\text {hub }}}{z_{0}}\right)}{\ln \left(\frac{z_{\text {anem }}}{z_{0}}\right)}$

where $z_{\text {hub }}$ is the hub height of the wind turbine in $m, z_{\text {anem }}$ is the anemometer height in $m, z_{0}$ is the surface roughness length in $m, V\left(z_{\text {hub }}\right)$ is wind speed at the hub height of the wind turbine in $\mathrm{m} / \mathrm{s}$ and $V\left(z_{\text {anem }}\right)$ is wind speed at anemometer height in $\mathrm{m} / \mathrm{s}$.

\section{Diesel fuel}

After high growth rates for several consecutive years and reaching around USD100/barrel in 2013 (Kojima 2016) oil price has experienced a sharp fall in the recent years and in 2017 it reached ca. USD 50/barrel. Following these changes, diesel price estimation for remote areas in Peru has decreased from 1.41 USD/L in 2013 (GIZ 2013) to 0.8 USD/L in 2017 (Global Petrol 2017).

\section{Considered configurations}

\section{Major components}

The major components of hybrid systems are photovoltaic panels, wind turbines, diesel generators, batteries, and power converters. Table 2 summarizes the capital, replacement and maintenance costs of all component of the hybrid system used in HOMER. 
Fig. 4 a Average monthly solar irradiation and $\mathbf{b}$ wind velocity for each location
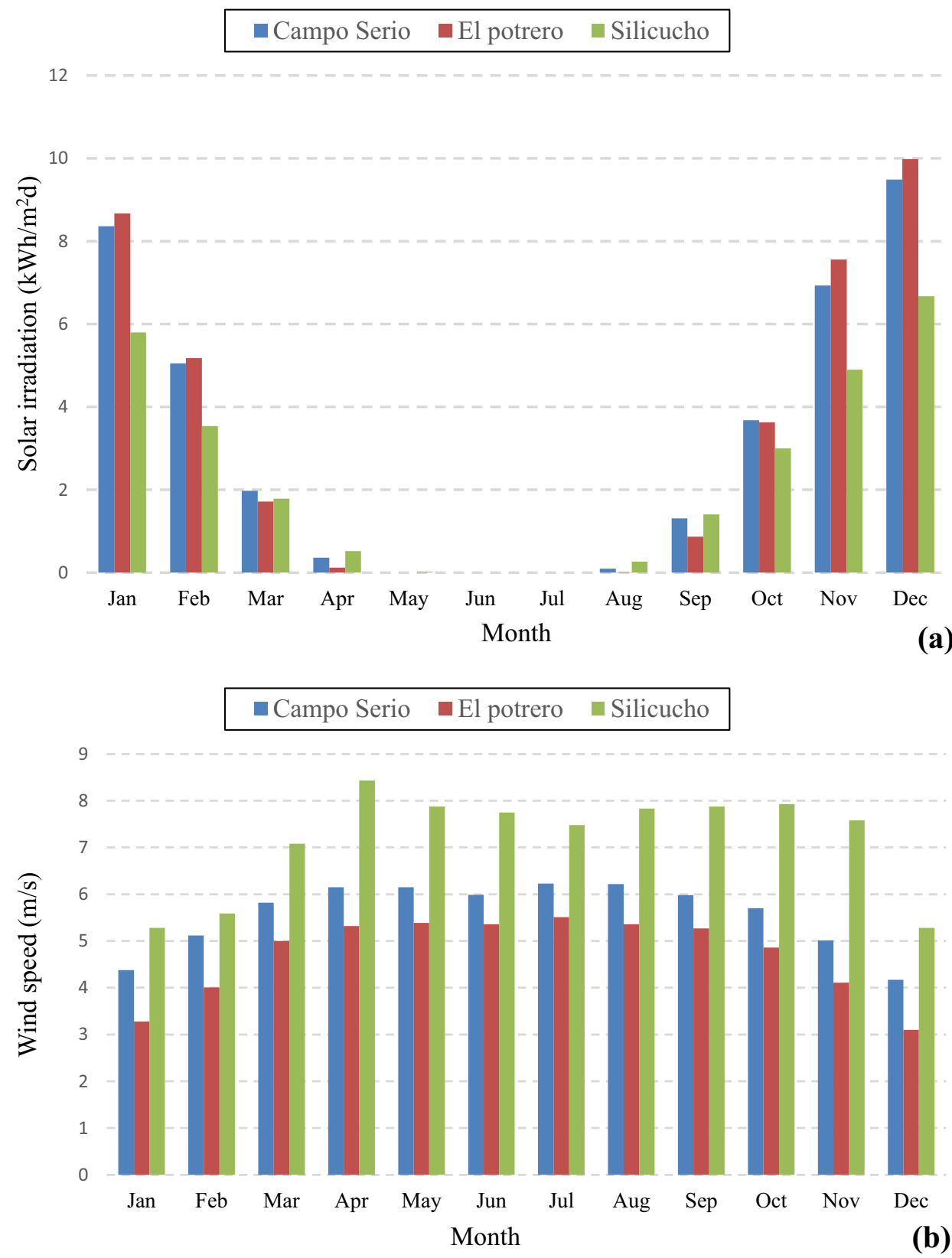

\section{Diesel generator}

Reliability of power systems which solely consist of renewable energy technologies is a matter of concern due to intermittent characteristics of RES (Arribas et al. 2010). To provide energy with high reliability while taking into account the sustainability, diesel generator system can be integrated with renewable energy systems. Diesel generators (Generac) with $15 \mathrm{~kW}, 20 \mathrm{~kW}, 30 \mathrm{~kW}$ or $48 \mathrm{~kW}$ rated power have been selected for this study and the corresponding costs are extracted from the corresponding website (Generac 2017). The operating lifetime is considered to be $20,000 \mathrm{~h}$ (HOMER Energy 2017a; Generac 2017). The replacement cost is considered to be $90 \%$ of the capital cost and yearly operation and maintenance cost is assumed to be $10 \%$ of the capital cost (Mamaghani et al. 2016a). To avoid wet stacking, which is a phenomenon that happens when diesel generator is idle for a long interval, minimum load ratio for diesel generator has been chosen to be $30 \%$ (HOMER Energy 2017b).

\section{Photovoltaic array}

Solar panel electricity generation systems, also known as solar photovoltaic, harness solar energy using photovoltaic cells and convert it into DC electricity energy in direct 
Table 2 Component data [obtained from: PV panel data: (Astronergy 2017), converter: (SolarEdge-Technologies-Inc. 2017), batteries: (Hoppecke-Batterien-GmbH 2017; Surrete-Ltd 2017), diesel generator: (Generac 2017), wind turbines: (Aeolos 2017)]

\begin{tabular}{llllll}
\hline Component & HOMER suffix & Capital cost & Replacement cost & Operation and maintenance & Fabricant \\
\hline PV 260 W & PV & USD 225 & USD 202.50 & USD 2.25/year & Astronergy \\
PV 305 W & PV & USD 235 & USD 211.50 & USD 2.35/year & Astronergy \\
Converter (5 kW) & Converter & USD 1275 & USD 1147.50 & USD 25.5/year & SolarEdge \\
Converter (6 kW) & Converter & USD 1377.88 & USD 1240.09 & USD 27.557/year & SolarEdge \\
Converter (7.6 kW) & Converter & USD 1589.74 & USD 1430.77 & USD 31.794/year & SolarEdge \\
Converter (10 kW) & Converter & USD 1963.13 & USD 1766.82 & USD 39.262/year & SolarEdge \\
Batteries (H3000) 2 V 3000 Ah & H3000 & USD 1157.69 & USD 1041.92 & USD 115.768/year \\
Batteries (4KS25P) 4 V 1900 Ah & S4KS25P & USD 1377.88 & USD 1240.09 & USD 137.788/year \\
Diesel Generator (15 kW) & Generator & USD 10,799 & USD 9719.10 & USD 0.123/ & Surrette \\
Diesel Generator (20 kW) & Generator & USD 12,149 & USD 10,934.10 & USD 0.138/year \\
Diesel Generator (30 kW) & Generator & USD 13,199 & USD 11,879.10 & USD 0.150/year \\
Diesel Generator (48 kW) & Generator & USD 16,199 & USD 14,579.10 & USD 0.184/year & Generac \\
Aeolos-H 10 kW 12 m monopole & AH10 & USD 19,545 & USD 17,590.50 & 267.042/year & Generac \\
Aeolos-H 20 kW 12 m monopole & AH20 & USD 36,170 & USD 32,553 & 494.189/year & Aeolos
\end{tabular}

proportion to the solar irradiation incident upon it (Liu et al. 2012). The power output of a solar panel can be calculated using Eq. (2).

$P_{\mathrm{PV}}=f_{\mathrm{PV}} Y_{\mathrm{PV}} \frac{I_{\mathrm{t}}}{I_{\mathrm{s}}}$

where $f_{\mathrm{PV}}$ is the $\mathrm{PV}$ derating factor; $Y_{\mathrm{PV}}$ the rated capacity of the PV array in $\mathrm{kW} ; I_{\mathrm{t}}$ the global solar irradiation incident on the surface of the PV array, in $\mathrm{kW} / \mathrm{m}^{2}$; and $I_{\mathrm{S}}$ the standard amount of irradiation used to rate the capacity of the PV array which is $1 \mathrm{~kW} / \mathrm{m}^{2}$. Derating factor originates from the PV panel power loss due to dust on the surface of the panels, shading and aging of panels, and elevated temperature. Following HOMER software's recommendation (HOMER Energy 2017a), the derating factor is considered to be 0.9 . Two low-cost $260 \mathrm{~W}$ and $305 \mathrm{~W}$ solar panels manufactured by Astronergy, which are based on Polycrystalline cells, have been chosen as the basis and the corresponding prices are obtained from the associated website (Astronergy 2017). The $260 \mathrm{~W}$ module (Astronergy CHSM6610P-260) has a surface area of $1.636 \mathrm{~m}^{2}$ (with dimensions of $1654 * 989 *$ $40 \mathrm{~mm}$ ), rated current of $8.48 \mathrm{~A}$, rated voltage of $30.90 \mathrm{~V}$ (both at standard testing conditions), and efficiency of 15.98\%. The $325 \mathrm{~W}$ module (Astronergy CHSM6612P-325) instead has a surface area of $1.934 \mathrm{~m}^{2}$ (with dimensions of $1954 * 990 * 40 \mathrm{~mm})$, rated current of $8.77 \mathrm{~A}$, rated voltage of $37.11 \mathrm{~V}$ (both at standard testing conditions), and efficiency of $16.8 \%$. Based on the specifications of the manufacture, the lifetime of the PV arrays is considered to be 25 years. The replacement cost is considered to be $90 \%$ of the capital cost, and the yearly operation and maintenance cost is considered to be $1 \%$ of the capital cost (Mamaghani et al. 2016a).

\section{Wind energy system}

Wind turbine is a device that converts kinetic energy of wind into electrical power. The power output for the wind turbine can be calculated employing Eq. (3) (Aeolos 2017).

$P_{\mathrm{wt}}=0.5 \rho v^{3} s \eta_{1} c_{\mathrm{p}}$

where $v$ is wind speed in $\mathrm{m} / \mathrm{s}, s$ is rotor swept area in $\mathrm{m}^{2}, \eta_{1}$ is generator efficiency, $c_{\mathrm{p}}$ is maximum power coefficient and $\rho$ is air density in $\mathrm{kg} / \mathrm{m}^{3}$. Wind turbines used in this analysis are Aeolos-H $10 \mathrm{~kW}$ and Aeolos-H $20 \mathrm{~kW}$ horizontal turbines with DC output and rated capacities of $10 \mathrm{~kW}$ and $20 \mathrm{~kW}$. For the case of Aeolos-H $10 \mathrm{~kW}$, cut-in wind speed is $2.5 \mathrm{~m} / \mathrm{s}$, rated wind speed is $10 \mathrm{~m} / \mathrm{s}$, cut-out wind speed is $18 \mathrm{~m} / \mathrm{s}$ and the sweep area is $44.2 \mathrm{~m}^{2}$. For the case of Aeolos-H $20 \mathrm{~kW}$ instead, cut-in wind speed is $3 \mathrm{~m} / \mathrm{s}$, rated wind speed is $10 \mathrm{~m} / \mathrm{s}$, cut-out wind speed is $20 \mathrm{~m} / \mathrm{s}$ and the sweep area is $78.5 \mathrm{~m}^{2}$ (Aeolos 2017). The capital cost of the wind energy system, obtained from Aeolos wind turbine catalogue (Aeolos 2017), accounts for the wind turbine, tower, inverter, wiring, painting, corrosion package, foundation, road construction and installation (Aeolos 2017). The replacement cost is considered to be $90 \%$ of the capital cost, and the considered lifetime for both models, extracted from the manufacturer's catalogue, is 20 years. The estimation of operating and maintenance $(\mathrm{O} \& \mathrm{M})$ costs appears to be strongly correlated with turbine's age. In the first few years of operation, considering the manufacturer's warranty, a low O\&M expenses can be expected; however, after 10 years, greater O\&M costs are considered owing to the needed repairing and the corresponding required reinvestments (Morthorst 2017). Based on the recommendations of 
a wind turbine installation firm (Natural Energy Renewables Ltd 2017), an average yearly maintenance is assumed to be $1.3 \%$ of the capital cost.

\section{Battery}

Battery stores electricity in a chemical form and subsequently this stored energy can be recharged and reused. Considering the fact that power production from renewables can fluctuate abruptly with weather conditions, to guarantee a reliable and constant power supply, battery storage has been utilized extensively. Battery storage can also be used to reduce the number of start/stop cycles of the backup diesel generator in hybrid systems (Nfah and Ngundam 2009). Two different types of lead acid batteries, Surrette (Surrete-Ltd 2017) and Hoppecke (Hoppecke-BatterienGmbH 2017) have been chosen as HOMER equivalent batteries for this analysis. The prices of each type of battery are extracted from the corresponding manufacturer's websites (Hoppecke-Batterien-GmbH 2017; Surrete-Ltd 2017); according to which, the lifetime of Surrette and Hoppecke can be considered to be 17 and 20 years. The replacement cost is assumed to be $90 \%$ of the capital cost. The yearly operation and maintenance cost is assumed to be $10 \%$ of the corresponding capital cost.

\section{Power converter}

In systems in which both AC and DC generating elements are dealt with, converter is an essential part of the system. HOMER software uses a converter, which is equivalent to both inverter and rectifier. The inverter is one of key components of a PV system which converts DC power from PV and battery output into AC one. In case of excess energy generation from wind turbines, rectifier converts $\mathrm{AC}$ power to DC to be stored in the battery storage system. SolarEdge converter with capacities of $5 \mathrm{~kW}, 6 \mathrm{~kW}, 7.6 \mathrm{~kW}$ and $10 \mathrm{~kW}$ have been selected for this analysis, the corresponding costs are obtained from the manufacturer's website (SolarEdgeTechnologies-Inc. 2017). The corresponding replacement cost is assumed to be $90 \%$ of the capital cost (Mamaghani et al. 2016a) and the yearly operation and maintenance cost is considered to be $10 \%$ of the capital cost (SolarEdge-Technologies-Inc. 2017). Converter and rectifier efficiencies are considered to be $98 \%$ and $85 \%$.

\section{Scenarios}

To conduct a comprehensive investigation on each location which covers all possible combinations of RES and diesel generator, seven different case scenarios are considered, among which the most favorable one for microgrid planning is determined. HOMER software has been employed to perform the economic optimization for each scenario and community.

As depicted in Fig. 5, the configurations analyzed in HOMER can be listed as:

- Diesel generator (Case 1)

- Photovoltaic (Case 2)

- Wind turbine (Case 3)

- Solar-wind hybrid (Case 4)

- Solar-wind-diesel hybrid (Case 5)

- Solar-diesel hybrid (Case 6)

- Wind-diesel hybrid (Case 7)

\section{Materials and methods}

While taking into account the meteorological data and load characteristics of the communities along with the diesel fuel's price and the cost of components, the optimal (most economical) sizing of the system utilizing different scenarios is determined. In the optimization procedure, the NPC is considered as the key economic index. The obtained configurations are then compared considering the other state-of-the-art economic indices together with the environmental metrics and the generation fractions. The indices which are employed in this study, including NPC, $\mathrm{COE}$, the initial capital cost, and the total annual operating cost along with the generation fractions are presented in this section.

\section{Net present cost (NPC)}

NPC represents the cost of a system during its lifetime. The considered costs include capital, replacement, O\&M (operation and maintenance), fuel, salvage, and penalties due to emissions. NPC can be calculated using Eq. (4):

$\mathrm{NPC}(\mathrm{USD})=\frac{\mathrm{TAC}}{\mathrm{CRF}}$

where TAC is the total annualized cost, CRF is the factor of returning capital given by Eq. (5):

$\mathrm{CRF}(\mathrm{USD})=\frac{i(1+i)^{N}}{(1+i)^{N}-1}$

where $N$ is the defined life time of the project (number of years) and $i$ is the annual interest. The replacement cost is utilized in order to take into account the economic impact of employing the components with a lower life time than that of the project. 
Fig. 5 The off-grid configurations analyzed in HOMER

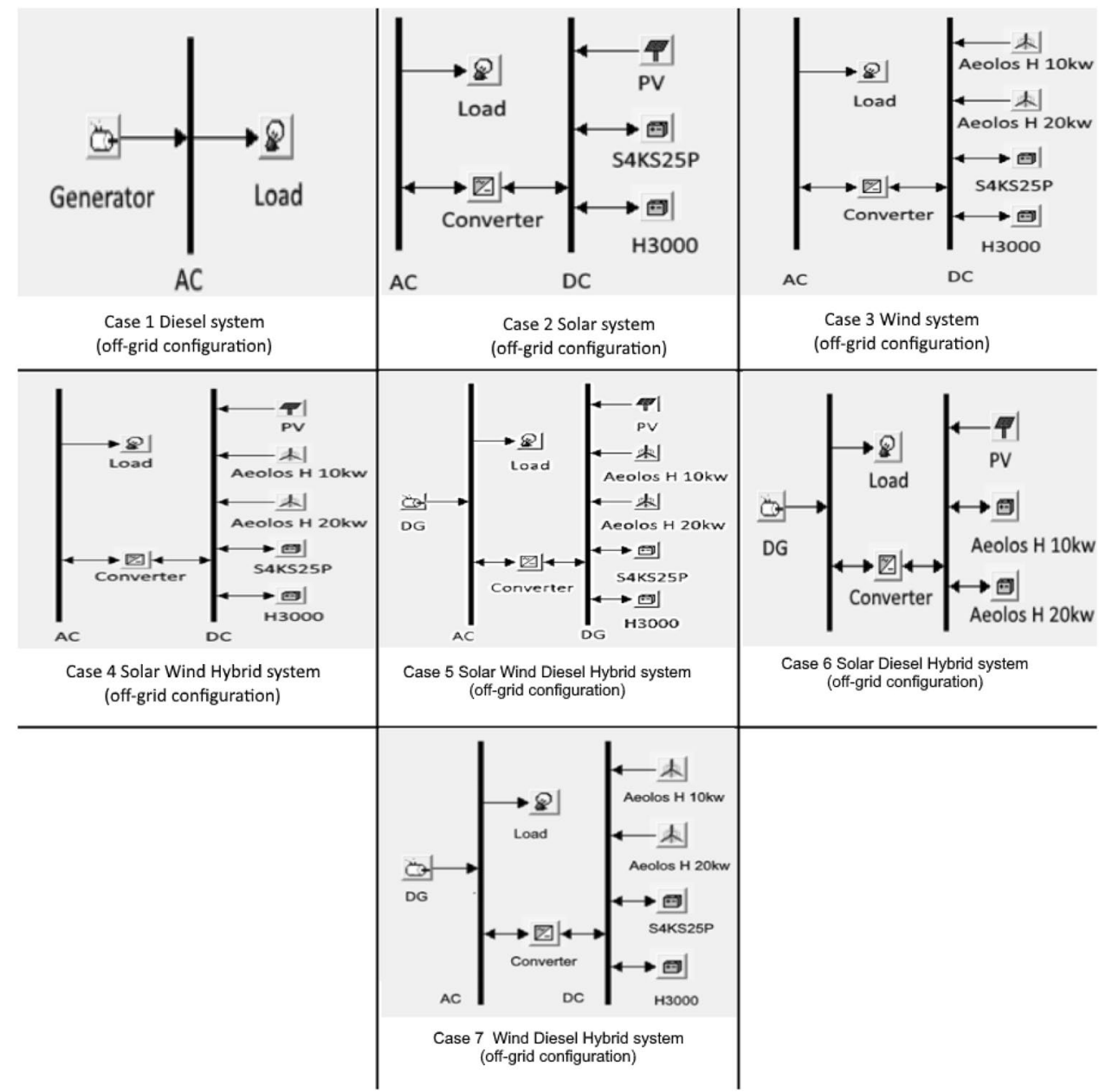

\section{Levelized cost of energy (COE)}

$\mathrm{COE}$ is the average cost per kilowatt hour (USD/kWh) of useful electrical energy produced by the system which is calculated using Eq. (6).

$\mathrm{COE}=\frac{C_{\mathrm{TANN}}}{E_{\mathrm{ls}}+E_{\mathrm{gr}}}$

where $E_{\mathrm{ls}}$ is the electrical energy that the microgrid is supplied with and $E_{\mathrm{gr}}$ is the amount of electricity sold to the grid by microgrid and $C_{\text {TANN }}$ is total annualized cost of the system (USD/year).

\section{Initial capital cost}

The initial capital cost is the total cost of all of the components at the beginning of the operation. In a system composed of batteries, wind turbines, solar panels, diesel generator and converter, the initial capital cost can be calculated utilizing Eq. (7).
Initial capital cost $=N_{\mathrm{b}} C_{\mathrm{b}}+\frac{P_{\mathrm{st}}}{P_{\mathrm{sb}}} C_{\mathrm{s}}+\frac{P_{\mathrm{wt}}}{P_{\mathrm{wb}}} C_{\mathrm{w}}+P_{\mathrm{gt}} C_{\mathrm{gref}}+\frac{P_{\mathrm{c}}}{P_{\mathrm{cb}}} C_{\mathrm{c}}$

where $N_{\mathrm{b}}$ is number of batteries, $C_{\mathrm{b}}$ is the price of battery energy system per each battery, $P_{\mathrm{st}}$ is the power produced by all the solar panels in $\mathrm{kW}, P_{\mathrm{sb}}$ is the power produced by one solar panel in $\mathrm{kW}, C_{\mathrm{s}}$ is the price of solar energy system per each solar panel, $P_{\mathrm{st}}$ is the power produced by all of the wind turbines in $\mathrm{kW} . P_{\mathrm{wb}}$ is instead the power produced by one wind turbine in $\mathrm{kW}, C_{\mathrm{w}}$ is the price of wind energy system per each wind turbine $C_{\mathrm{w}}$ is the price of wind energy system per each wind turbine, $P_{\mathrm{gt}}$ is the total power produced by the diesel generator in $\mathrm{kW}, C_{\text {gref }}$ is the price of $1 \mathrm{~kW}$ generator. $P_{\mathrm{gt}}$ is the power of the converter, $P_{\mathrm{gt}} P_{\mathrm{cb}}$ is the power of base converter and $C_{\mathrm{c}}$ is price of the base converter.

\section{Total annual operating cost (TOC)}

The operating costs are the expenses corresponding to the operation of all of the components of the system in 1 year. Total operating cost can be calculated using Eq. (8): 
$\mathrm{TOC}=\sum_{i=1}^{n} C_{\mathrm{OM}, i}+C_{f}+\sum_{i=1}^{n} C_{R, i}-\sum_{i=1}^{n} C_{S, i}$

where $\mathrm{n}$ is the number of components of the system, $C_{\mathrm{OM}, i}$ is the annual operation and maintenance (O\&M) cost for $i$ th component of the system, $C_{\mathrm{f}}$ is annual total fuel cost, $C_{\mathrm{R}, \mathrm{i}}$ is annualized replacement cost for $i$ th component of the system and $C_{\mathrm{S}, \mathrm{i}}$ is the salvage value of component $i$. In HOMER, the components are considered to depreciate linearly; the salvage value of a component is directly proportional to its remaining life.

\section{Fractions of generation}

The RF, as specified in Eq. (9), is the ratio of the electrical production originating from renewable power sources to the total electrical production:

$f_{\text {ren }}=\frac{E_{\text {ren }}}{E_{\text {tot }}}$

where $E_{\text {ren }}$ is renewable electrical production $(\mathrm{kWh})$ and $E_{\text {tot }}$ is the total electrical production $(\mathrm{kWh})$. Based on the approach proposed by Celik (2002), the fraction of energy that each source is generating can be subsequently calculated. As expressed in Eqs. 10 and 11, photovoltaic fraction $E_{\mathrm{pv}} F_{\mathrm{pv}}$ and the wind generation fraction $E_{\mathrm{pv}} F_{\mathrm{pv}} F_{\mathrm{wg}}$ are expressed by the ratio of energy produced by $\operatorname{solar}\left(E_{\mathrm{pv}}\right)$ and wind $\left(E_{\mathrm{wg}}\right)$ generation units to the total generated electrical energy $E_{\text {tot }}$.

$F_{\mathrm{pv}}=\frac{E_{\mathrm{pv}}}{E_{\mathrm{tot}}}$
$F_{\text {wg }}=\frac{E_{\text {wg }}}{E_{\text {tot }}}$

The fraction of energy produced by the diesel generator can be similarly defined (Eq. 12).

$F_{\mathrm{dg}}=\frac{E_{\mathrm{dg}}}{E_{\mathrm{tot}}}$

where $E_{\mathrm{pv}} E_{\mathrm{dg}}$ is the energy produced by the diesel generator.

\section{Results and discussion}

For each considered community, the achieved optimal sizing of the system, considering the cases $1-7$, is represented in Tables 3, 4 and 5. As can be observed in these tables, to compare the proposed configurations from the economic point of view, four indicators, namely initial capital of the system (in terms of USD), operating cost (USD/year), total NPC (USD) and COE (USD/kWh), were selected. The latter indices provided an in depth information about the economic perspective of each system and facilitate the determination of the most economically convenient case for each location. To assess these configurations from an environmental standpoint, the yearly $\mathrm{CO}_{2}$ production for each case has been calculated. The overall yearly production of $\mathrm{PV}$, wind and diesel generation units are also determined for each case.

\section{Optimized designs for Campo serio in Loreto region}

The optimization results and the corresponding costs of investigated scenarios for Campo serio are represented in Fig. 6 and Table 3. As can be observed in Fig. 6, considering

Table 3 Optimized results for the proposed configurations in Campo serio

\begin{tabular}{|c|c|c|c|c|c|c|c|}
\hline & Case 1 (diesel) & Case 2 (solar) & Case 3 (wind) & $\begin{array}{l}\text { Case } 4 \\
\text { (solar, wind) }\end{array}$ & $\begin{array}{l}\text { Case } 5 \text { (solar, } \\
\text { wind, diesel) }\end{array}$ & $\begin{array}{l}\text { Case } 6 \\
\text { (solar, } \\
\text { diesel) }\end{array}$ & $\begin{array}{l}\text { Case } 7 \\
\text { (wind, } \\
\text { diesel) }\end{array}$ \\
\hline PV $(\mathrm{kW})$ & - & 130 & - & 20 & 40 & 110 & 0 \\
\hline Generator $(\mathrm{kW})$ & 20 & - & - & - & 10 & 10 & 10 \\
\hline Convertor $(\mathrm{kW})$ & - & 20 & 20 & 20 & 20 & 20 & 20 \\
\hline$F_{\mathrm{pv}}(\%)$ & 0 & 100 & 0 & 28 & 57 & 89 & 0 \\
\hline$F_{\text {dg }}(\%)$ & 100 & 0 & 0 & 0 & 6 & 11 & 11 \\
\hline$F_{\mathrm{wg}}(\%)$ & 0 & 0 & 100 & 72 & 37 & 0 & 89 \\
\hline PV (kWh/year) & - & 132,949 & - & 18,490 & 36,979 & 101,693 & 0 \\
\hline DG (kWh/year) & 58,780 & - & - & - & 3968 & 12,744 & 6157 \\
\hline Wind (kWh/year) & - & - & 143,150 & 47,717 & 23,858 & 0 & 47,717 \\
\hline $\mathrm{CO}_{2}$ emissions ( $\mathrm{kg} /$ year) & 74,391 & - & - & - & 4578 & 14,699 & 7102 \\
\hline Renewable fraction (-) & 0 & 100 & 100 & 100 & 93.9 & 88.9 & 88.6 \\
\hline $\begin{array}{l}\text { Annual operation hours of } \\
\text { generator }(\mathrm{h})\end{array}$ & 8759 & - & - & - & 416 & 1333 & 645 \\
\hline
\end{tabular}


Table 4 Optimized results for the proposed configurations in El potrero

\begin{tabular}{|c|c|c|c|c|c|c|c|}
\hline & Case 1 (diesel) & Case 2 (solar) & Case 3 (wind) & $\begin{array}{l}\text { Case } 4 \\
\text { (solar, wind) }\end{array}$ & $\begin{array}{l}\text { Case } 5 \text { (solar, } \\
\text { wind, diesel) }\end{array}$ & $\begin{array}{l}\text { Case } 6 \\
\text { (solar, } \\
\text { diesel) }\end{array}$ & $\begin{array}{l}\text { Case } 7 \\
\text { (wind, } \\
\text { diesel) }\end{array}$ \\
\hline PV $(k W)$ & - & 120 & - & 10 & 20 & 60 & 0 \\
\hline Generator $(\mathrm{kW})$ & 20 & - & - & - & 10 & 10 & 10 \\
\hline Convertor $(\mathrm{kW})$ & - & 20 & 20 & 20 & 20 & 20 & 20 \\
\hline$F_{\mathrm{pv}}(\%)$ & 0 & 100 & 0 & 19 & 47 & 87 & 0 \\
\hline$F_{\mathrm{dg}}(\%)$ & 100 & 0 & 0 & 0 & 3 & 13 & 10 \\
\hline$F_{\mathrm{wg}}(\%)$ & 0 & 0 & 100 & 81 & 50 & 0 & 90 \\
\hline PV (kWh/year) & - & 143,357 & - & 11,332 & 22,664 & 67992 & 0 \\
\hline DG (kWh/year) & 55,011 & - & - & - & 1650 & 10,341 & 5603 \\
\hline Wind (kWh/year) & - & - & 144,005 & 48,002 & 24,001 & 0 & 48,002 \\
\hline $\mathrm{CO}_{2}$ emissions ( $\mathrm{kg} /$ year $)$ & 70,263 & - & - & - & 1903 & 11,916 & 6459 \\
\hline Renewable fraction (-) & 0 & 100 & 100 & 100 & 96.6 & 86.8 & 89.5 \\
\hline $\begin{array}{l}\text { Annual operation hours of } \\
\text { generator }(\mathrm{h})\end{array}$ & 8759 & - & - & - & 171 & 1060 & 580 \\
\hline
\end{tabular}

Table 5 Optimized results for the proposed configurations in Silicucho

\begin{tabular}{|c|c|c|c|c|c|c|c|}
\hline & Case 1 (diesel) & Case 2 (solar) & Case 3 (wind) & $\begin{array}{l}\text { Case } 4 \\
\text { (solar, wind) }\end{array}$ & $\begin{array}{l}\text { Case } 5 \text { (solar, } \\
\text { wind, diesel) }\end{array}$ & $\begin{array}{l}\text { Case } 6 \\
\text { (solar, } \\
\text { diesel) }\end{array}$ & $\begin{array}{l}\text { Case } 7 \\
\text { (wind, } \\
\text { diesel) }\end{array}$ \\
\hline $\mathrm{PV}(\mathrm{kW})$ & - & 140 & - & 20 & 50 & 90 & 0 \\
\hline Generator $(\mathrm{kW})$ & 10 & - & - & - & 10 & 10 & 10 \\
\hline Convertor $(\mathrm{kW})$ & - & 10 & 10 & 10 & 10 & 10 & 10 \\
\hline$F_{\mathrm{pv}}(\%)$ & 0 & 100 & 0 & 25 & 76 & 93 & 0 \\
\hline$F_{\mathrm{dg}}(\%)$ & 100 & 0 & 0 & 0 & 6 & 7 & 17 \\
\hline$F_{\mathrm{wg}}(\%)$ & 0 & 0 & 100 & 75 & 18 & 0 & 83 \\
\hline PV (kWh/year) & - & 109,455 & - & 15,724 & 39,309 & 70,757 & 0 \\
\hline DG (kWh/year) & 30,434 & - & - & - & 3285 & 5189 & 4892 \\
\hline Wind (kWh/year) & - & - & 72,289 & 48,193 & 9182 & 0 & 24,096 \\
\hline $\mathrm{CO}_{2}$ emissions ( $\mathrm{kg} /$ year) & 38,333 & - & - & - & 3786 & 5980 & 5738 \\
\hline Renewable fraction (-) & 0 & 100 & 100 & 100 & 93.7 & 93.2 & 82.9 \\
\hline $\begin{array}{l}\text { Annual operation hours of } \\
\text { generator }(\mathrm{h})\end{array}$ & 8759 & - & - & - & 338 & 533 & 507 \\
\hline
\end{tabular}

the NPC, case 5 (solar and wind and diesel) is the most economical scenario. It can be noticed though that for case 1 , in which only the diesel generator is used to cater the demand, the required initial capital cost is much lower than the other cases; indeed, its corresponding initial cost (USD 12,149 ) is almost one-ninth of that of case 5. Despite the fact that the low initial capital investment for diesel generators seems desirable to investors, a long-term analysis reveals that case 5 is the most cost-effective configuration resulting in the lowest NPC.

By comparing the operating hour of the diesel generator for cases 5 and 1 , indicated in Table 3 , it is observed that the corresponding value is diminished by 21 times through utilizing PV and wind technology, which is desirable considering the corresponding emission reduction (Asrari et al.
2012). Considering the operating hour of diesel generator, case 5 is indeed demonstrated to be the most promising configuration among the case which include a diesel generator (cases 1, 5, 6, and 7) resulting in the highest RF.

Figure 6 also demonstrates that case 2 (stand-alone solar) is the most costly one resulting in a significantly higher NPC with respect to the other cases. The key difference between the cases 2 and 5 is the power provided by the diesel generator during the winter in which the lack of solar irradiation tremendously decreases the power output of solar panels.

Table 3 also demonstrates that three case scenarios with the lowest NPC are case 4, case 5, and case 7 . In case 4 and case 7 , the majority of energy is produced by wind turbines, while the majority of supplied energy in case 5 is provided by PV panels. It can also be observed that case 4, 
Fig. 6 System costs associated with each case investigated for Campo serio; \$:USD

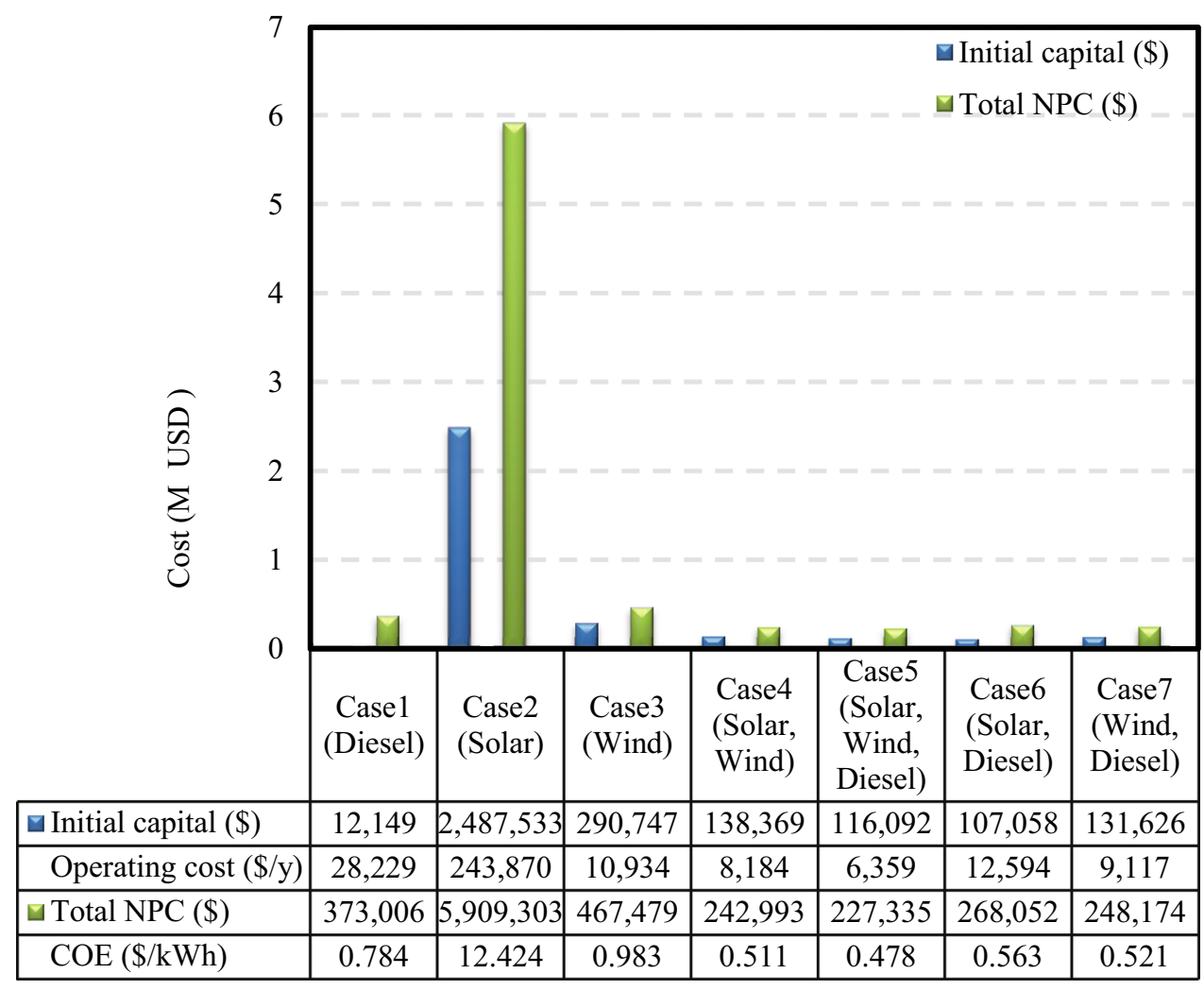

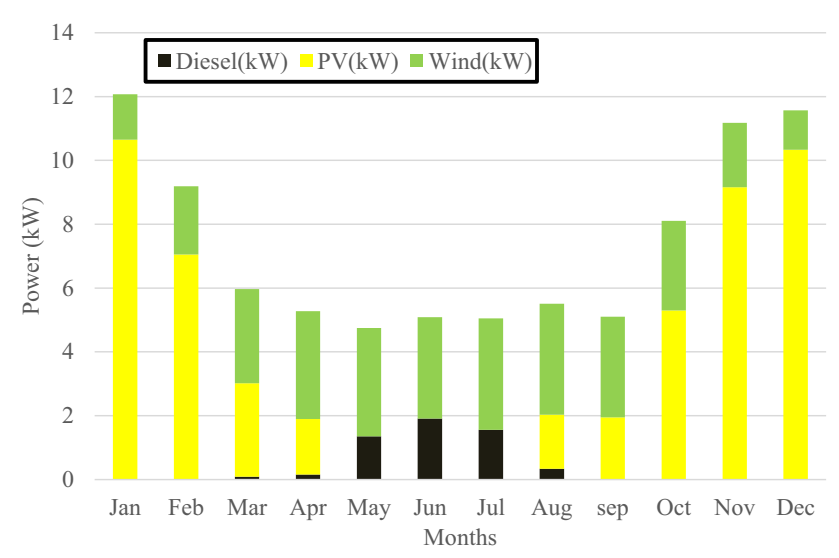

Fig. 7 Total electricity production in case 5 for campo serio

with the RF of $100 \%$, is the greenest configuration among the scenarios with the least NPCs.

Figure 7 shows the productions of solar, wind and diesel generation units for the optimal configuration of case 5 throughout the year. It can be observed that during the months with a notable solar irradiation (October to February), the PV generation constitutes the major role in the overall electricity production. On the other hand, in the winter months, and particularly during the months of May, June, and July, the PV generation is almost negligible and the corresponding lack of production is compensated by the diesel generator.

\section{Optimized designs for El potrero in Cajamarca region}

Table 4 and Fig. 8 represent the optimized results and the corresponding costs of all investigated scenarios for El potrero. As observed in Table 4, the three case scenarios with the lowest NPC are case 4 (solar, wind), case 5 (solar, wind, diesel) and case 6 (solar, diesel). Solar panels supply $87 \%$ of overall generation in case 6 , while wind turbines produce $81 \%$ and $50 \%$ of total generation in case 4 and case 5. Among the three cases with the lowest NPC, case 4 is the most environment-friendly scenario leading to the renewable fraction of $100 \%$. As can be observed in Fig. 8, similar to the obtained results for Campo serio, case 5, with the lowest NPC, is the most economical configuration and case 1 is the configuration requiring the lowest initial cost. The latter is due to the low cost of diesel generators compared to renewable energy system components, though the elevated cost of this plan in the long run, and particularly its emissions, devalue the benefit of utilizing this scheme. As demonstrated in Table 4, diesel generator operating hour in case 5 is approximately one fifties of that of case 1 . 
Fig. 8 System costs associated with each case investigated for El potrero; \$:USD

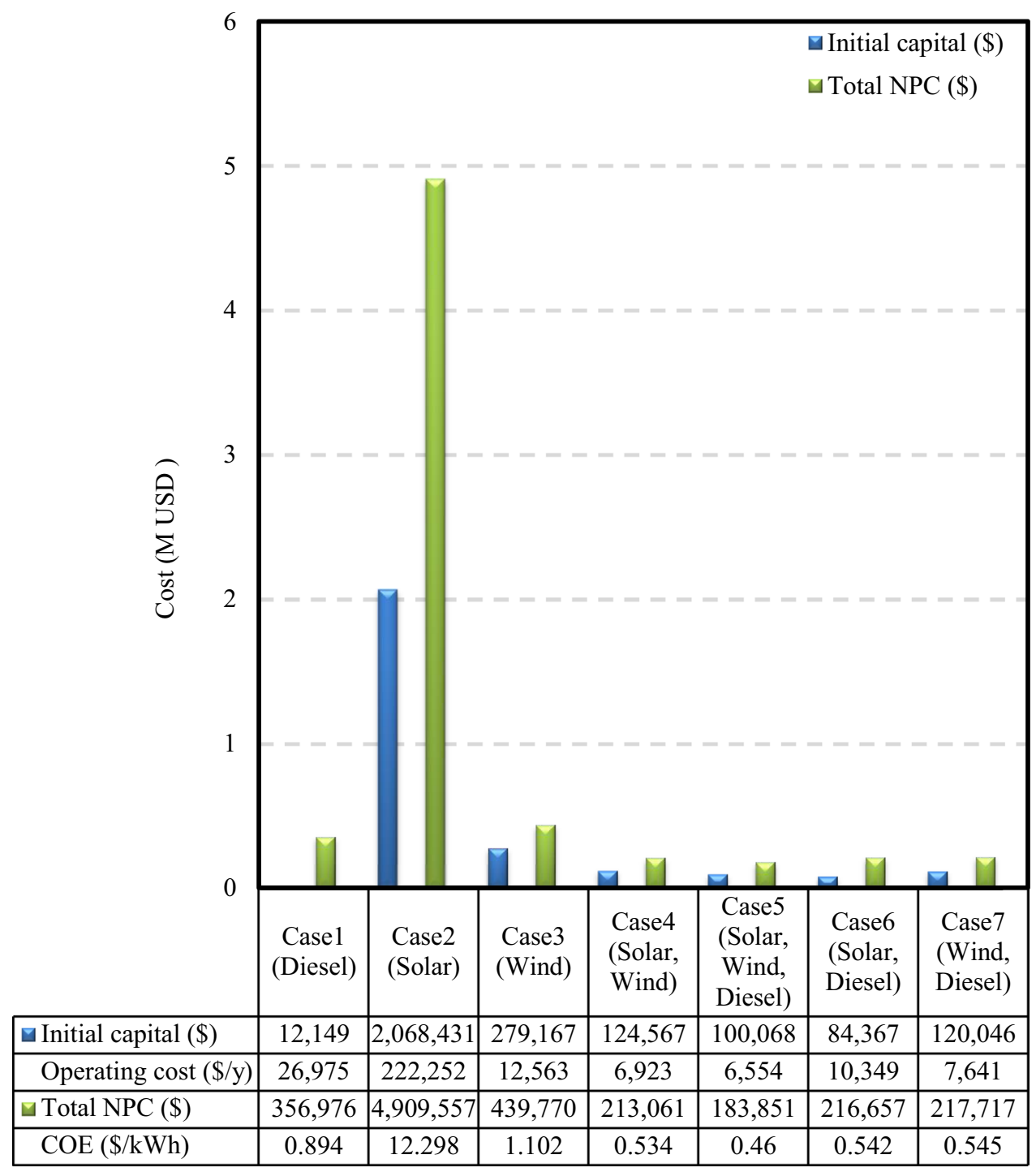

\section{Optimized designs for Silicucho in Puno region}

The obtained optimal sizing and the resulting costs, employing different scenarios, for Silicucho are demonstrated in Table 5 and Fig. 9. As indicated in Fig. 9, three case scenarios with the lowest NPC are case 4, case 5 and case 7 and, similar to the previous regions, case 5 is first most economically viable configuration among the hybrid systems, case 1 still has the lowest initial cost, and case 2 is the scenario leading to the highest NPC.

Case 6, as shown in Table 5, is the most environmentfriendly configuration among the scenarios running partly with diesel generator. The resulting carbon dioxide emission employing the configuration of case 6 is far less than the one corresponding to case 1 .

Although, as demonstrated in Fig. 4b, the average wind speed in Silicucho is notably higher than the other two areas, the wind generation fraction of the corresponding optimal configuration is considerably lower than the one of Campo serio and $\mathrm{El}$ potrero. The latter is due to the fact that, as shown in Fig. 3, the average electricity consumption and peak load of Silicucho is lower than the other two villages. As demonstrated in Table 6, while the economic optimization results in choosing a $20 \mathrm{~kW}$ wind turbine for Campo serio and $\mathrm{El}$ potrero, a $10 \mathrm{~kW}$ wind turbine is selected for Silicucho. The corresponding wind-based power production is considerably lower which leads to a notably lower wind generation fraction. The latter fact demonstrates the necessity of conducting a comprehensive optimization in which the available renewable resources, load characteristics, and the economic indices are taken into account. 
Fig. 9 System costs associated with each case investigated for Silicucho; \$:USD

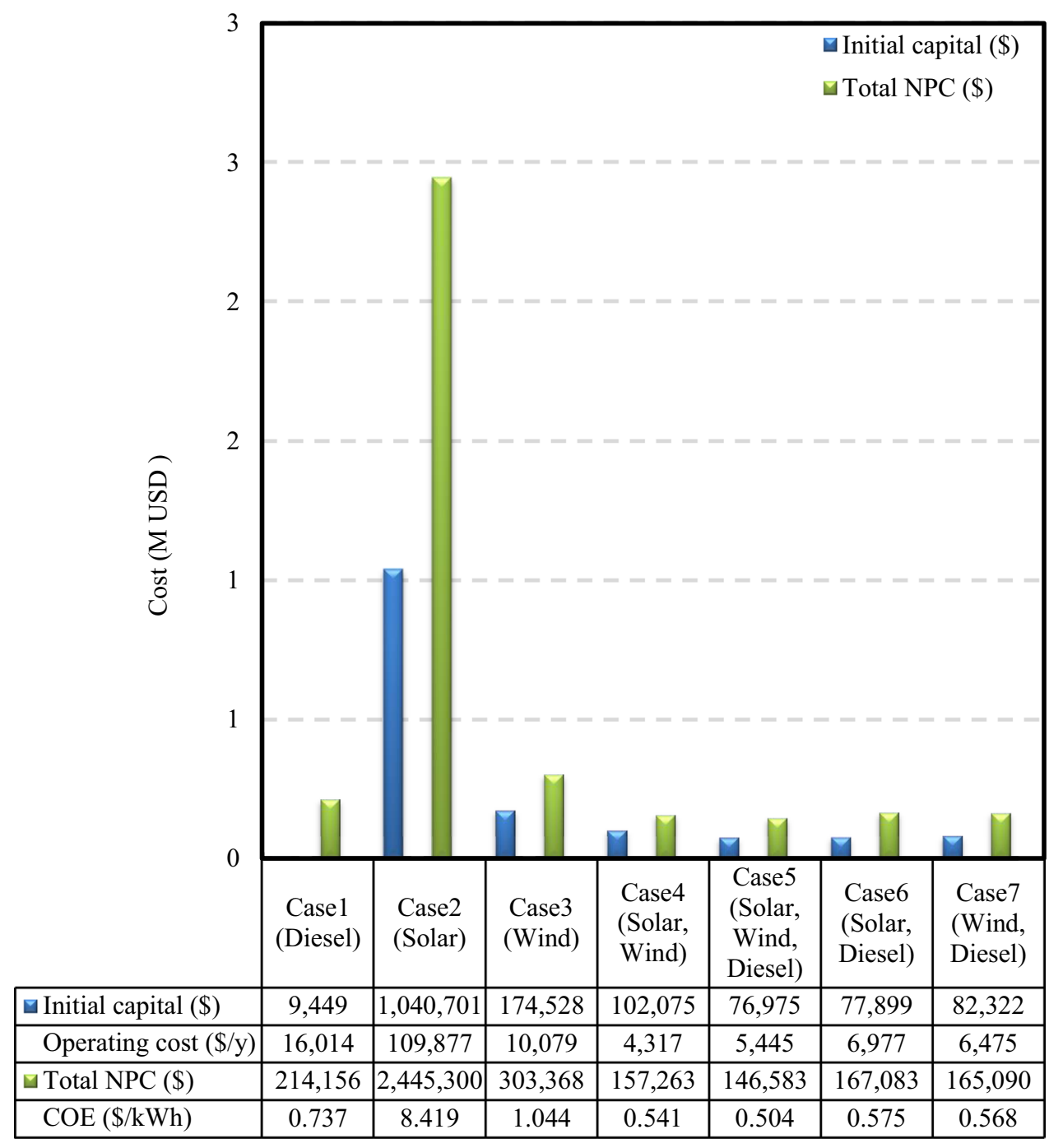

Table 6 The nominal capacity of main system components of the optimal hybrid plant (case 5)

\begin{tabular}{llllll}
\hline Location & PV $(\mathrm{kW})$ & $\begin{array}{l}\text { Wind } \\
\text { turbine } \\
(\mathrm{kW})\end{array}$ & $\begin{array}{l}\text { Gen- } \\
\text { erator } \\
(\mathrm{kW})\end{array}$ & No. of battery & $\begin{array}{l}\text { Con- } \\
\text { verter } \\
(\mathrm{kW})\end{array}$ \\
\hline Campo serio & 40 & 20 & 10 & 50 & 20 \\
El potrero & 20 & 20 & 10 & 40 & 20 \\
Silicucho & 50 & 10 & 10 & 30 & 10
\end{tabular}

\section{Conclusions}

Techno-economic performance of stand-alone electricity generation systems for off-grid communities located in different climatic areas of Peru was investigated. Seven scenarios, including different combinations of diesel generators, wind turbine units, and solar panels, were assessed. Optimal sizing of each configuration, which minimizes the corresponding NPC, was determined and the achieved optimal systems were also evaluated considering other economic indices and their environmental performance. The analysis demonstrated that, for all of the investigated communities, the hybrid solar-wind-diesel system is the most economically viable configuration. For the case of Campo serio, although the initial capital cost of the dieselonly configuration is almost one-ninth of that of the mentioned hybrid system, the latter results in the lowest NPC in a long-term analysis. For the case of Campo serio, the optimal configuration requires an initial capital of USD 116,092 , and corresponds to an operating cost of 6359 USD/y, a total NPC of USD 227,335 and a COE of 0.4738 USD/kWh.

The optimal hybrid configuration for Campo serio resulted in renewable fraction of $94 \%$ leading to $4578 \mathrm{~kg} / \mathrm{y}$ of $\mathrm{CO}_{2}$ emissions which is $6.1 \%$ of the emissions of the diesel-only configuration $\left(23,858 \mathrm{~kg} / \mathrm{y}\right.$ of $\mathrm{CO}_{2}$ emissions). The latter ratio is determined to be $2.7 \%$ for the case of $\mathrm{El}$ 
potrero and $9.9 \%$ for Silicucho. The variance in the obtained ratios is due to differences in the availability of renewable sources and the load characteristics of the considered areas.

The Peruvian authority can play a notable role in facilitating the utilization of such technologies in the rural areas. A depreciation regime for the income tax is the only support which is presently provided to the RES-based electricity generation plant in Peru. In case adequate incentive policies would be provided, the COE of the proposed system will be notably reduced which will aid the mentioned communities to install the proposed systems.

Acknowledgements Open access funding provided by Politecnico di Milano within the CRUI-CARE Agreement.

Open Access This article is licensed under a Creative Commons Attribution 4.0 International License, which permits use, sharing, adaptation, distribution and reproduction in any medium or format, as long as you give appropriate credit to the original author(s) and the source, provide a link to the Creative Commons licence, and indicate if changes were made. The images or other third party material in this article are included in the article's Creative Commons licence, unless indicated otherwise in a credit line to the material. If material is not included in the article's Creative Commons licence and your intended use is not permitted by statutory regulation or exceeds the permitted use, you will need to obtain permission directly from the copyright holder. To view a copy of this licence, visit http://creativecommons.org/licenses/by/4.0/.

\section{References}

Aeolos (2017) Wind turbine catalogue. www.windturbinestar.com/ products.html. Last accessed 15 Nov 2017

Ajlan A, Tan CW, Abdilahi AM (2017) Assessment of environmental and economic perspectives for renewable-based hybrid power system in Yemen. Renew Sustain Energy Rev 75:559-570. https ://doi.org/10.1016/j.rser.2016.11.024

Alsharif MH (2017) Optimization design and economic analysis of energy management strategy based on photovoltaic/energy storage for heterogeneous cellular networks using the HOMER model. Sol Energy 147:133-150

Aminyavari M, Mamaghani AH, Shirazi A, Najafi B, Rinaldi F (2016) Exergetic, economic, and environmental evaluations and multi-objective optimization of an internal-reforming SOFC-gas turbine cycle coupled with a Rankine cycle. Appl Therm Eng 108:833-846

Arceo A, Rosano M, Biswas WK (2018) Eco-efficiency analysis for remote area power supply selection in Western Australia. Clean Technol Environ Policy 20:463-475. https://doi.org/10.1007/ s10098-017-1438-6

Arribas L, Cano L, Cruz I, Mata M, Llobet E (2010) PV-wind hybrid system performance: a new approach and a case study. Renew Energy 35:128-137. https://doi.org/10.1016/j.renene.2009.07.002

Asrari A, Ghasemi A, Javidi MH (2012) Economic evaluation of hybrid renewable energy systems for rural electrification in Iran: a case study. Renew Sustain Energy Rev 16:3123-3130. https://doi. org/10.1016/j.rser.2012.02.052

Astronergy (2017) Astronergy PV modules catalogue. www.astronergy .com/products_download.php. Last accessed 08 Nov 2017

Bekele G, Boneya G (2012) Design of a photovoltaic-wind hybrid power generation system for ethiopian remote area. Energy Proc 14:1760-1765. https://doi.org/10.1016/j.egypro.2011.12.1164
Bekele G, Palm B (2010) Feasibility study for a standalone solarwind-based hybrid energy system for application in Ethiopia. Appl Energy 87:487-495. https://doi.org/10.1016/j.apene rgy.2009.06.006

Bentouba S, Bourouis M (2016) Feasibility study of a wind-photovoltaic hybrid power generation system for a remote area in the extreme south of Algeria. Appl Therm Eng 99:713-719. https:// doi.org/10.1016/j.applthermaleng.2015.12.014

Brandoni C, Bošnjaković B (2017) HOMER analysis of the water and renewable energy nexus for water-stressed urban areas in SubSaharan Africa. J Cleaner Prod 155(Part 1):105-118. https://doi. org/10.1016/j.jclepro.2016.07.114

Celik AN (2002) Optimisation and techno-economic analysis of autonomous photovoltaic-wind hybrid energy systems in comparison to single photovoltaic and wind systems. Energy Convers Manag 43:2453-2468. https://doi.org/10.1016/S0196-8904(01)00198-4

Dekker J, Nthontho M, Chowdhury S, Chowdhury SP (2012) Economic analysis of PV/diesel hybrid power systems in different climatic zones of South Africa. Int J Electr Power Energy Syst 40:104-112. https://doi.org/10.1016/j.ijepes.2012.02.010

Diab F, Lan H, Ali S (2016) Novel comparison study between the hybrid renewable energy systems on land and on ship. Renew Sustain Energy Rev 63:452-463. https://doi.org/10.1016/j.rser.2016.05.053

Dorji T, Urmee T, Jennings P (2012) Options for off-grid electrification in the Kingdom of Bhutan. Renew Energy 45:51-58. https://doi. org/10.1016/j.renene.2012.02.012

Flores HFV, Furubayashi T, Nakata T (2016) Decentralised electricity generation system based on local renewable energy sources in the Honduran rural residential sector. Clean Technol Environ Policy 18:883-900. https://doi.org/10.1007/s10098-015-1067-x

Fragaki A, Markvart T (2008) Stand-alone PV system design: results using a new sizing approach. Renew Energy 33:162-167. https:// doi.org/10.1016/j.renene.2007.01.016

Generac (2017) Diesel generator price. www.generac.com/Industrial/ products/diesel-generators. Last accessed 13 Oct 2017

Global Petrol (2017) Peru diesel prices 2017. www.globalpetrolprices. com/Peru/gasoline_prices/. Last accessed 25 Oct 2017

GIZ GMBh (2013) 2012/2013 International fuel prices. (Deutsche Gesellschaft flir Internationale Zusammenarbeit (GIZ)), www. sutp.org/publications/international-fuel-prices-2012-2013/. Last accessed 10 Nov 2017

Goodbody C (2013) Regional integration of renewable energy systems in Ireland: the role of hybrid energy systems for small communities. Int J Electr Power Energy Syst 44:713-720. https://doi. org/10.1016/j.ijepes.2012.08.012

Gu W, Wang J, Lu S, Luo Z, Wu C (2017) Optimal operation for integrated energy system considering thermal inertia of district heating network and buildings. Appl Energy 199:234-246. https://doi. org/10.1016/j.apenergy.2017.05.004

Hafez O, Bhattacharya K (2012) Optimal planning and design of a renewable energy based supply system for microgrids. Renew Energy 45:7-15. https://doi.org/10.1016/j.renene.2012.01.087

Homer Energy (2017a) HOMER Pro 3.10 user guide. www.homerenerg y.com/products/pro/docs/3.10/index.html. Last accessed 15 Nov 2017

HOMER Energy (2017b) Generator minimum load ratio. www.homer energy.com/products/grid/docs/latest/generator_minimum_load_ ratio.html. Last accessed 20 Nov 2017

Hoppecke-Batterien-GmbH (2017) Battery catalogue. www.hoppecke.com/ de/produkte/powerline-industriebatterien/. Last accessed 18 Nov 2017

Hossain FM, Hasanuzzaman M, Rahim NA, Ping HW (2015) Impact of renewable energy on rural electrification in Malaysia: a review. Clean Technol Environ Policy 17:859-871. https://doi. org/10.1007/s10098-014-0861-1

Hossain M, Mekhilef S, Olatomiwa L (2017) Performance evaluation of a stand-alone PV-wind-diesel-battery hybrid system feasible 
for a large resort center in South China Sea, Malaysia. Sustain Cities Soc 28:358-366. https://doi.org/10.1016/j.scs.2016.10.008

Hrayshat ES (2009) Off-grid hybrid wind-diesel power plant for application in remote Jordanian settlements. Clean Technol Environ Policy 11:425-436. https://doi.org/10.1007/s10098-009-0200-0

INEI (2012) Geographical and population consultation center of Peru, http://sige.inei.gob.pe/test/atlas/. Last accessed 15 Oct 2017

Irena (2014) Peru Renewable readiness assesment. www.irena.org/ publications/2014/Jun/Renewables-Readiness-Assessment-Peru. Last accessed 16 Oct 2017

Kalantar M, Mousavi GSM (2010) Dynamic behavior of a stand-alone hybrid power generation system of wind turbine, microturbine, solar array and battery storage. Appl Energy 87:3051-3064. https ://doi.org/10.1016/j.apenergy.2010.02.019

Kanase-Patil AB, Saini RP, Sharma MP (2010) Integrated renewable energy systems for off grid rural electrification of remote area. Renew Energy 35:1342-1349. https://doi.org/10.1016/j.renen e.2009.10.005

Khan MJ, Iqbal MT (2005) Pre-feasibility study of stand-alone hybrid energy systems for applications in Newfoundland. Renew Energy 30:835-854. https://doi.org/10.1016/j.renene.2004.09.001

Khare V, Nema S, Baredar P (2016) Optimization of hydrogen based hybrid renewable energy system using HOMER, BB-BC and GAMBIT. Int J Hydrog Energy 41:16743-16751. https://doi. org/10.1016/j.ijhydene.2016.06.228

Kojima M (2016) Fossil fuel subsidy and pricing policies recent developing country experience. World Bank. https://doi. org/10.1596/1813-9450-7531

Lilienthal TGaP (2015) Using HOMER ${ }^{\circledR}$ software, NREL's micropower optimization model, to explore the role of gen-sets in small solar power systems case study, Sri Lanka

Liu G, Rasul MG, Amanullah MTO, Khan MMK (2012) Techno-economic simulation and optimization of residential grid-connected PV system for the Queensland climate. Renew Energy 45:146155. https://doi.org/10.1016/j.renene.2012.02.029

Mamaghani AH, Avella SAE, Najafi B, Rinaldi F, Shirazi A (2016a) Techno-economic feasibility of photovoltaic, wind, diesel and hybrid electrification systems for off-grid rural electrification in Colombia. Renew Energy 2016:293-305

Mamaghani AH, Najafi B, Casalegno A, Rinaldi F (2016b) Longterm economic analysis and optimization of an HT-PEM fuel cell based micro combined heat and power plant. Appl Therm Eng 99:1201-1211

Mamaghani AH, Najafi B, Casalegno A, Rinaldi F (2017) Predictive modelling and adaptive long-term performance optimization of an HT-PEM fuel cell based micro combined heat and power (CHP) plant. Appl Energy 192:519-529

Marneni A, Kulkarni AD, Ananthapadmanabha T (2015) Loss reduction and voltage profile improvement in a rural distribution feeder using solar photovoltaic generation and rural distribution feeder optimization using HOMER. Proc Technol 21:507-513. https:// doi.org/10.1016/j.protcy.2015.10.036

MINEM Peru (2008) Master plan of rural electrification with renewable energy. Plan Nacional de Electrificacion Rural PNER, Repulica del Peru Ministerio de Energia y Minas. https://openjicareport.jica. go.jp/pdf/11893195_01.pdf. Accessed 22 Nov 2017

Montuori L, Alcázar-Ortega M, Álvarez-Bel C, Domijan A (2014) Integration of renewable energy in microgrids coordinated with demand response resources: economic evaluation of a biomass gasification plant by Homer Simulator. Appl Energy 132:15-22. https://doi.org/10.1016/j.apenergy.2014.06.075

Morthorst PE (2017) Wind energy the fact, cost and prices, vol 2. NEI-DK-4555. 2004, European wind Energy association, Brussels, Belgium

Najafi B, Najafi H, Idalik M (2011) Computational fluid dynamics investigation and multi-objective optimization of an engine air-cooling system using genetic algorithm. Proc Inst Mech Eng C J Mech Eng Sci 225:1389-1398

Najafi B, Mamaghani AH, Rinaldi F, Casalegno A (2015) Fuel partialization and power/heat shifting strategies applied to a $30 \mathrm{~kW}$ el high temperature PEM fuel cell based residential micro cogeneration plant. Int J Hydrog Energy 40:14224-14234

NASA (2017) NASA atmospheric science data center, http://eoswe b.larc.nasa.gov/cgi-bin/sse/homer.cgi. Last accessed 25 Oct 2017

Natural Energy Renewables Ltd (2017) Wind turbine installation recommendation, www.naturalenergyuk.co.uk/. Last accessed via communication 15 Oct 2017

Nfah EM, Ngundam JM (2009) Feasibility of pico-hydro and photovoltaic hybrid power systems for remote villages in Cameroon. Renew Energy 34:1445-1450. https://doi.org/10.1016/j.renen e.2008.10.019

Rajbongshi R, Borgohain D, Mahapatra S (2017) Optimization of PVbiomass-diesel and grid base hybrid energy systems for rural electrification by using HOMER. Energy 126:461-474. https://doi. org/10.1016/j.energy.2017.03.056

Rajkumar RK, Ramachandaramurthy VK, Yong BL, Chia DB (2011) Techno-economical optimization of hybrid PV/wind/battery system using neuro-fuzzy. Energy 36:5148-5153. https://doi. org/10.1016/j.energy.2011.06.017

Ray A, Jana K, Assadi M, De S (2018) Distributed polygeneration using local resources for an Indian village: multiobjective optimization using metaheuristic algorithm. Clean Technol Environ Policy 20:1323-1341. https://doi.org/10.1007/s10098-018-1562-y

Rehman S, El-Amin IM, Ahmad F et al (2007) Feasibility study of hybrid retrofits to an isolated off-grid diesel power plant. Renew Sustain Energy Rev 11:635-653. https://doi.org/10.1016/j. rser.2005.05.003

Roy A, Kulkarni GN (2016) Analysis on the feasibility of a PV-diesel generator hybrid system without energy storage. Clean Technol Environ Policy 18:2541-2553. https://doi.org/10.1007/s1009 8-015-1070-2

SE4ALL (2014) PERU: rapid assessment and gap analysis. http://sefor all.org/sites/default/files/Peru_RAGA_EN_Released.pdf. Last accessed 15 Nov 2017

Shaahid SM, Elhadidy MA (2007) Technical and economic assessment of grid-independent hybrid photovoltaic-diesel-battery power systems for commercial loads in desert environments. Renew Sustain Energy Rev 11:1794-1810. https://doi.org/10.1016/j. rser.2006.03.001

Shezan SA, Saidur R, Ullah KR, Hossain A, Chong WT, Julai S (2015) Feasibility analysis of a hybrid off-grid wind-DG-battery energy system for the eco-tourism remote areas. Clean Technol Environ Policy 17:2417-2430. https://doi.org/10.1007/s10098-015-0983-0

Singh A, Baredar P (2016) Techno-economic assessment of a solar PV, fuel cell, and biomass gasifier hybrid energy system. Energy Rep 2:254-260. https://doi.org/10.1016/j.egyr.2016.10.001

SolarEdge-Technologies-Inc (2017) Inverter catagloue. www.solar edge.com/sites/default/files/commercial-catalogue-na.pdf. Last accessed 12 Nov 2017

Surrete-Ltd (2017) Battery catalogue. www.rollsbattery.com/catalog/. Last accessed 10 Nov 2017

Valente LCG, De Almeida SCA (1998) Economic analysis of a diesel/ photovoltaic hybrid system for decentralized power generation in northern Brazil. Energy 23:317-323

Yousefi M, Kim JH, Hooshyar D, Yousefi M, Sahari KSM, Ahmad RB (2017) A practical multi-objective design approach for optimum exhaust heat recovery from hybrid stand-alone PV-diesel power systems. Energy Convers Manag 142:559-573. https://doi. org/10.1016/j.enconman.2017.03.031

Zahboune H, Zouggar S, Krajacic G, Varbanov PS, Elhafyani M, Ziani E (2016) Optimal hybrid renewable energy design in autonomous system using modified electric system cascade analysis and 
Homer software. Energy Convers Manag 126:909-922. https:// doi.org/10.1016/j.enconman.2016.08.061

Publisher's Note Springer Nature remains neutral with regard to jurisdictional claims in published maps and institutional affiliations. 